УДК 681.62.067.6

\title{
ДОСЛІДЖЕННЯ ПРОЦЕСУ ТРАНСПОРТУВАННЯ ТА ВИКЛАДАННЯ ВІДДРУКОВАНОЇ ПРОДУКЦІЇ НА ПРИЙМАЛЬНИЙ СТАПЕЛЬ АРКУШЕВИХ ДРУКАРСЬКИХ МАШИН
}

\author{
( І. В. Кулинич, магістр, Ю. О. Шостачук, К.т.н., доцент, НТУУ \\ «КПІ», Київ, Україна
}

\section{Статья посвящена исследованию процесса транспортирова- ния и вывода отпечатаной продукции на приемный стапель листовых офсетных печатных машин.}

The Article is devoted research of process of transportation and a conclusion of printing production in discharge and bundling sections of sheet offset printing machines.

\section{Постановка проблеми}

Вивідні та приймальні пристрої є надзвичайно важливою частиною друкарської машини, адже від якості їх роботи безпосередньо залежить час виготовлення та якість готової продукції. Постійно зростаючий попит на поліграфічну продукцію вимагає конструктивних змін друкарського обладнання. В першу чергу це стосується робочих швидкостей машин, використання різноманітного спектру існуючих матеріалів із широким діапазоном товщин, комбінування різних фарб та лаків, збільшення фарбовості відбитків та подальшої універсалізації обладнання. Із зростанням вимог до продукції зростають і вимоги до устаткування, що вимагає всебічного вивчення роботи приймальновивідних пристроїв та факторів, які впливають на процес виведення та укладання віддрукованої продукції у стапель [1-3].
Процес зйому листа 3 друкарського циліндра починається 3 моменту передачі листа із захоплювачів друкарського ци-ліндра в захоплювачі аркушевивідного пристрою і закінчується моментом втрати задньою кромкою листа контакту 3 поверхнею циліндра. При цьому не повинно відбуватися пошкодження кромок листів та змазування нанесенного зображення. Після знімання листа 3 друкарського циліндра його задрукована поверхня повинна мати мінімальний контакт з рухомими елементами та вивідними напрямними. Для цього використовуються спеціальні опорні елементи, які забезпечують мінімальну площу контакту, а також «повітряну подушку» для виключення будь-якого контакту з механічними частинами машини.

Сам процес знімання листа 3 друкарського циліндра супроводжується його згинанням в хвостовій частині при відриві від 
офсетного циліндра. Явище згину листа, як показує практика експлуатації машин, викликає їх скручування, утворення так званих «локонів». Це проявляється в задній частині відбитка і суттєво ускладнює процес стапелювання [2-4].

Для покращення викладу листів в аркушеприймальному пристрою сучасних друкарських машин встановлюються додаткові модулі: для сповільнення руху та гальмування листа, розгладжування задньої кромки листа, напрямні 3 «повітряною подушкою», а також елементи формування якісного приймального стапеля. Для цього використовуються повітродувні пристрої у вигляді регульованих повітряних трубок, розташованих на шляху проведення листів і сприяючих проведенню листів у повітряному полі без контакту з рухомими та нерухомими елементами машини. Крім того, повітряна система забезпечує швидке і ефективне опускання відбитків на приймальний стіл.

Формування рівного стапеля, яке необхідне для подальших обробних процесів і прискорення виготовлення готової продукції, здійснюється за допомогою розташованих з трьох сторін стопи бокових та задніх зіштовхувачів. До приймальних та вивідних пристроїв ставляться наступні вимоги:

- надійний вивід і рівне укладання відбитків різноманітних форматів і маси без їх пошкодження, змазування зображення і перетискування фарби на всіх швидкостях роботи машини;
- викладення віддрукованих відбитків віддрукованою стороною вверх;

- можливість контролю якості відбитків і розвантаження приймального стола при роботі машини.

Слід зауважити, що швидкість друкування на сучасних листових ротаційних машинах досягає 5 м/с, а швидкість підходу листів до передніх упорів для запобігання пошкодження листів і забезпечення їх рівного укладання у стос не повинна перевищувати 0,6$0,8 \mathrm{~m} / \mathrm{c}[1,3,4]$.

\section{Аналіз попередніх досліджень}

Аркуш паперу, знаходячись в машині, зазнає впливу різних видів навантажень, одночасно змінюючи як характер, так і напрям руху. Навантаження можуть носити як рівномірний, так і ударний характер, можуть бути точковими і розподіленими, поздовжніми і поперечними, розтягуючими і стискаючими, здавлюючими і роздираючими. Характер руху також може бути різним: стан спокою, рівномірного прямолінійного руху, прискореного і сповільненого руху по різного роду криволінійним траєкторіям. У відповідь на різноманітні навантаження і в залежності від характеру руху та властивостей лист проявляє різні характеристичні властивості [5, 6].

Відбиток передається із захоплювачів друкарського циліндра останньої друкарської секції машини в захоплювачі ланцюгового транспортера. При досягненні кареткою з пе- 
реднім краєм листа відповідної точки відносно приймального столу, захоплювачі відпускають лист, одночасно «хвіст» відбитка гальмується сповільнюючим пристроєм. Передній край листа змінює напрямок руху і під дією інерційних сил досягає передніх упорів. Зустріч 3 передніми упорами супроводжується ударом з наступним відскакуванням та опусканням на поверхню стапеля, де вирівнюється відносно стопи за допомогою зіштовхувального пристрою [1, 3].

Для забезпечення якісного виводу та укладання листів у стапель сучасний приймальний пристрій оснащений вакуумним сповільнюючим модулем, який повинен погасити частину кінетичної енергії листа. Величина кінетичної енергії залежить від швидкості роботи машини і маси відбитка. Гальмування виконується в жорстких циклових обмеженнях, оскільки за дуже короткий проміжок часу необхідно для правильної укладки в стапель погасити швидкість листа до допустимої, мінімізувати величину його відскоку після зустрічі з передніми упорами і не допустити зминання кромок вивідною кареткою, яка транспортує наступний лист $[1,3]$.

\section{Мета роботи}

Метою даного дослідження $€$ дослідження процесу транспортування листів та їх укладання у стос з визначенням можливих шляхів оптимізації параметрів приймально-вивідних пристроїв листових офсетних друкарських машин.

\section{Результати проведених досліджень}

Сучасні друкарські машини характеризуються суттєвим підвищенням швидкості, фарбовості та розширенням спектру друкованих матеріалів. До роботи приймально-вивідних пристроїв, які забезпечують викладання листів та формування стапеля, ставляться особливі вимоги.

Процес виводу листів із друкарської секції на приймальний стіл і укладання їх у стапель складається з декількох стадій:

- передача листа із захоплювачів друкарського циліндра в захоплювачі аркушевивідного транспортера;

- змінний рух листа до приймального столу в захоплювачах аркушевивідної каретки до моменту їх відкривання;

- вільний політ листа 3 моменту його звільнення із захоплювачів каретки до моменту удару по передніх упорах;

- удар листа по передніх упорах та його відскокування 3 наступним його опусканням на приймальний стапель;

- вирівнювання листів в стапелі (зіштовхування).

Процес знімання задрукованого листа 3 друкарського циліндра і передача його в захоплювачі вивідної каретки супроводжується його скручуванням в хвостовій частині, що є наслідком деформації листа при друкуванні. Це проявляється особливо при роботі з тонкими паперами (до 80 г/м²). Транспортування листа супроводжується значними аеродинамічним навантаженням на його поверхню. Особливо це проявляється при 
переході листа з прямолінійної ділянки на криволінійну (переміщення каретки з листом по зростаючій похилій траєкторії), коли лист намагається по інерції зберегти свій початковий напрямок руху, в результаті чого виникає його хвилясте викривлення (рис. 1). При високих швидкостях роботи машини папір також схильний до деформації та вібрацій внаслідок повітряних потоків, які виникають при русі вивідних кареток.

Проведений аналіз технологічного процесу виведення задрукованих листів дозволив визначити основні фактори та їх вплив під час транспортування та викладення листів у стапель. Всі фактори впливу об'єднані у дві групи:

1) технологічні: зволожувальний розчин; фарба; тиск при друкуванні; нанесення противідмарювального порошку; лак (за наявності); сушіння;
2) механічні: тиск та розтягування захоплювачами приймально-вивідного пристрою; прогини під дією потоків повітря у процесі укладання; розтягнення внаслідок взаємодії з вакуумним гальмівним пристроєм; удар по переднім, боковим та заднім упорам приймального столу.

Для детального дослідження параметрів механізмів приймально-вивідного пристрою та наведених факторів процес виведення відбитка був розбитий на три окремі стадії. На першій стадії відбувається транспортування аркушів від друкарської секції до приймального модуля на висоту стапеля за допомогою вивідного транспортера на швидкості роботи машини (швидкість друкування). Аркуш із захоплювачів друкарського циліндра 3 передається в захоплювачі транспортера в точці А (рис. 2) при швидкості друку-

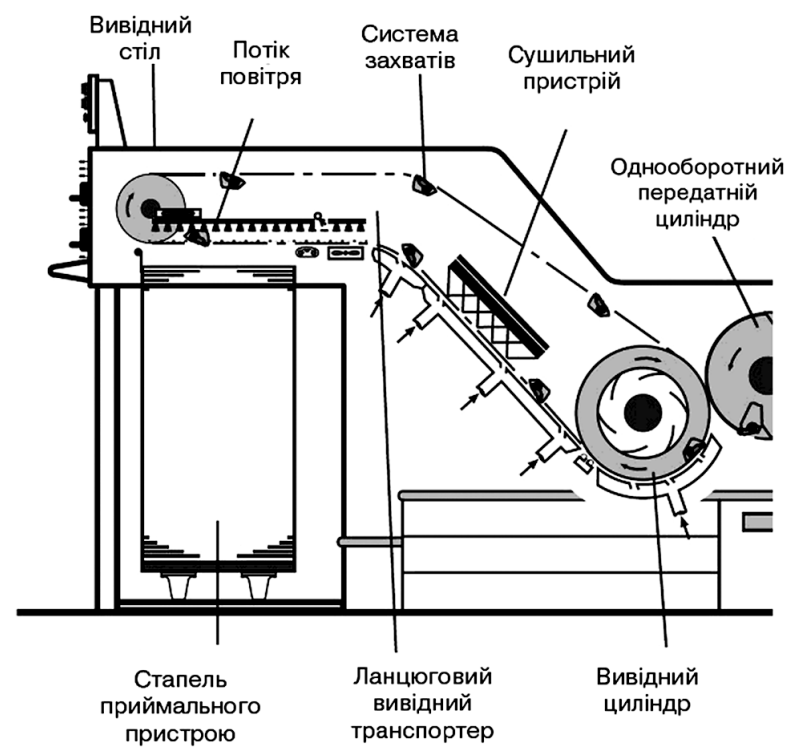

Рис. 1. Схема транспортування та виводу надрукованої продукції у листових друкарських машинах 


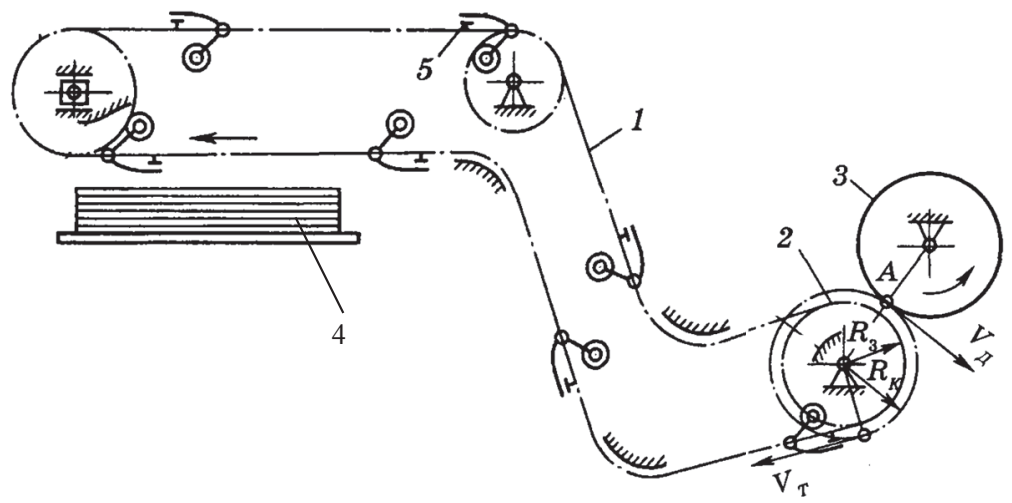

Рис. 2. Схема ланцюгового вивідного транспортера 1 - ланцюговий транспортер вивідного модуля; 2 - приводне зубчасте колесо;

3 - друкарський циліндр останньої секції; 4 - стапель; 5 - захоплювачі вивідного модуля

вання $\mathrm{V}_{\text {д }}=\mathrm{R}_{\mathrm{k}} \cdot \omega$, де $\mathrm{R}_{\mathrm{k}}-$ радіус зубчастого колеса, що приводить у рух приводний вал транспортера; $\omega-$ кутова швидкість приводного вала транспортера.

Далі, на прямолінійній ділянці, транспортер веде аркуш зі швидкістю $\mathrm{V}_{\mathrm{T}}=\mathrm{R}_{3} \cdot \omega$, де $\mathrm{R}_{3}$ - радіус приводної зірочки. Величина зменшення швидкості може бути оцінена коефіцієнтом сповільнення швидкості $\beta$ :

$$
\beta=\frac{\mathrm{V}_{4}}{\mathrm{~V}_{\mathrm{\prime}}}=\frac{\mathrm{R}_{\mathrm{:}} \omega}{\mathrm{R}_{7} \omega}=1+\frac{\mathrm{R}_{:}-\mathrm{R}_{7}}{\mathrm{R}_{7}} .
$$

За рахунок такої конструктивної зміни радіусів зірочки та напрямних руху вивідних кареток можна добитися сповільнення руху відбитка на 15-20 \%.

Друга стадія виведення відбитка характеризується зміною напрямку руху листа відносно стапеля і його контактом 3 вакуумним сповільнюючим пристроєм (рис. 3). Переміщення листа можна описати наступною залежністю:

$$
x=\chi_{0}+v_{0 x} t+\left(a_{x} t^{2} / 2\right)
$$

$$
v_{0 X}=\omega \cdot R_{3},
$$

де $\omega=2 \pi n-$ кутова швидкість приводної зірочки (1/с); n - частота обертання друкарського циліндра і, відповідно, приводної зірочки (об/с), Rз - радіус приводної зірочки (м); $\chi_{0}-$ координата знаходження листа відносно передньої кромки стапеля (м); $v_{0 x}$ і $\alpha_{x}-$ відповідно швидкість та прискорення листа в момент початку сповільненого руху; $\mathrm{t}$ - час, за який лист досягає передніх упорів (с).

Дослідження та розрахунки показали, що швидкість виведення відбитку захоплювачами ланцюгового вивідного транспортера при максимальній швидкості роботи машини (18000 від/год) становить $\mathrm{V}_{\mathrm{T}}=$ $=5,024$ м/с. При цьому значення допустимої швидкості відбитка в момент підходу до передніх упорів для стабільного викладу та мінімізації пошкоджень листів не повинно превищувати $\mathrm{V}_{\text {д }}=0,8 \mathrm{~m} / \mathrm{c}$. Це означає, що для стабільного викладу 


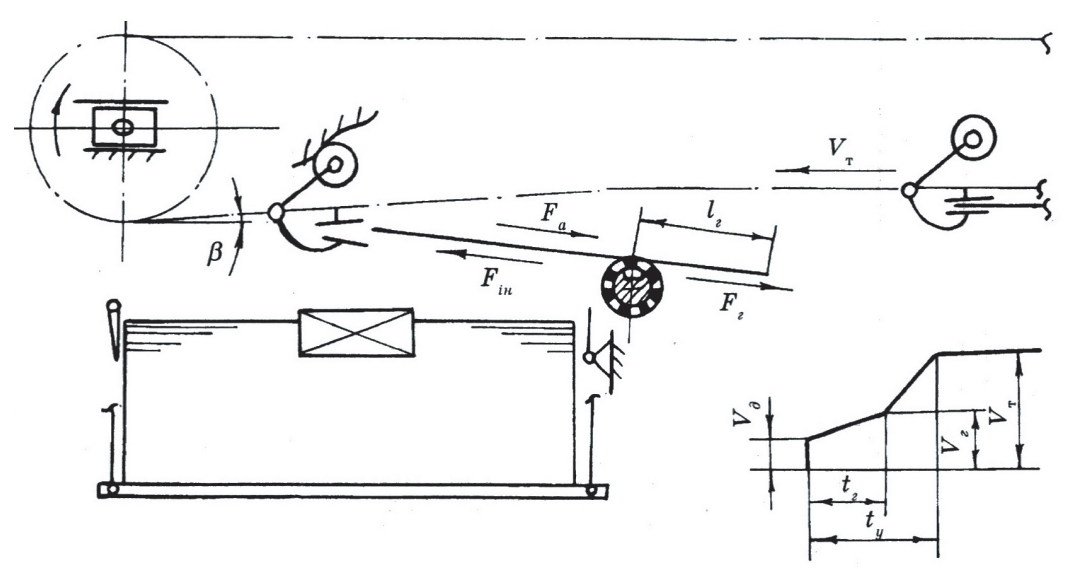

a

б

Рис. 3. Розрахункова схема вивідного транспортера із сповільнюючим пристроєм (а - принципова схема процесу виводу та стапелювання листів, б - діаграма зміни швидкості руху листів)

листів і остаточного формування стапелю необхідно забезпечити суттєву зміну швидкості руху листа у момент підходу до передніх упорів.

Сповільнення швидкості руху відбувається внаслідок дії сил тертя аркуша по поверхні напрямних та вакуумних роликів $F_{г}$ та аеродинамічної сили $\mathrm{F}_{\mathrm{a}}$ і визначається умовою рівності кінетичної енергії:

$$
\frac{m\left(V_{T}^{2}-V_{\Gamma}^{2}\right)}{2}=\Delta p S_{K} \mathrm{fL}_{\Gamma}+F_{a} L_{y} \text {, }
$$

де $\mathrm{m}$ - маса листа; $\mathrm{V}_{г}$ швидкість гальмівних роликів; $\Delta \mathrm{p}=\mathrm{p}_{\mathrm{a}}-\mathrm{p}_{1}-$ величина перепаду тиску повітря при присмоктування листа $\left(\mathrm{p}_{\mathrm{a}}=10^{5}\right.$ Па - атмосферний тиск повітря, $p_{1}-$ тиск в отворі штока гальмівної системи; $\mathrm{S}_{\mathrm{K}}$ - сумарна площа контакту листа і гальмівних елементів; $\mathrm{f}$ - коефіцієнт тертя листа по напрямним ( $f=0,02[7]) ; L_{г}-$ величина контакту листа при взаємодії з гальмівними вакуум- ними роликами (залежить від виду і характеристик матеріалів і може становити до $30 \%$ від довжини твірної друкарського циліндра); $\mathrm{L}_{\mathrm{y}}$ - шлях листа до переднього упору від моменту його відпускання захоплювачами транспортера (залежить від виду і характеристик матеріалів, швидкості друкування, складності зображення і може становити до 10-50 \% від довжини листа).

У лівій частині рівняння (4) знаходяться змінні параметри, які задані технологічно і залежать від маси, формату, допустимої швидкості друку і швидкості транспортування листа вивідним транспортером. У правій частині знаходяться параметри, які в процесі роботи машини можуть бути змінені: величина вакууму (p), швидкість гальмівних роликів $\left(\mathrm{V}_{г}\right)$, які встановлюються та регулюються в залежності від конструктивних особливостей машини. 
Аеродинамічна сила $F_{a}$ в правій частині формули (4) визначається з рівняння:

$$
\mathrm{F}_{\mathrm{a}}=\mathrm{K}_{0} \cdot \rho_{0} \cdot \mathrm{V}_{\mathrm{T}}^{2} \cdot \mathrm{S}_{\mathrm{a}}
$$

де $\mathrm{S}_{\mathrm{a}}$ - площа листа; $\rho_{0}$ - густина повітря $\left(\rho_{0}=1,205 \mathrm{k} / \mathrm{M}_{3}\right.$ [7]); $\mathrm{K}_{0}$ - коефіцієнт опору (залежить від форми, яку набуває лист при укладанні в стапель, для випадку прямолінійного виводу листа $\mathrm{K}_{0}=0,026$ [7]).

Значення аеродинамічних сил для форматів листа В3 та В1 при різних швидкостях роботи машини наведені в табл. 1.

Принцип сповільнення руху базується на присмоктуванні хвостової частини листа вакуумними роликами, величина присмоктування яких залежить від величини розрідження в системі. Лінійна швидкість роликів $€$ меншою від лінійної швидкості каретки, що дозволяє зменшити швидкість руху листа $\mathrm{V}_{\mathrm{T}}$ (рис. 4).
Для ефективного впливу та можливості корегування швидкості руху листа необхідно визначити величину розрідження у сповільнюючому пристрої (на листових машинах максимальне розрідження становить $3 \cdot 10^{4}$ Па).

3 формули (4) маємо:

$$
p=\frac{m\left(V_{T}^{2}-V_{\Gamma}^{2}\right)-2 F_{a} L_{y}}{S f L_{\Gamma}},
$$

де $\mathrm{S}=\sum_{1}^{\mathrm{n}} \mathrm{S}_{\mathrm{i}}$ - сума площ отворів, розташованих на поверхні вакуумних роликів. Результати дослідження залежності величини розрідження від формату, маси (з врахуванням заповнення листа) та швидкості представлені графічно на рис. 4. Отримані величини характеризують зусилля гальмування $F_{g}$ в залежності від матеріалів та їх характеристик (табл. 2):

$$
F_{g}=p S_{\kappa}
$$

Таблиця 1 Залежність аеродинамічних сил від формату та швидкості роботи машини

\begin{tabular}{|c|c|c|}
\hline Швидкість (об/год) & В3 (н) & В1 (н) \\
\hline 8000 & 0,029 & 0,118 \\
\hline 12000 & 0,066 & 0,265 \\
\hline 15000 & 0,103 & 0,415 \\
\hline 18000 & 0,148 & 0,597 \\
\hline
\end{tabular}

Таблиця 2

Необхідна величина зусилля гальмування $\mathrm{F}_{\mathrm{g}}$ в залежності

від формату, маси матеріалів та швидкості машини

\begin{tabular}{|c|c|c|c|c|c|c|}
\hline $\begin{array}{c}\text { Швидкість } \\
\text { об/год }\end{array}$ & $\begin{array}{c}\mathrm{B} 3, \mathrm{~m}_{\min } \\
/ \mathrm{H} /\end{array}$ & $\begin{array}{c}\mathrm{B} 3, \mathrm{~m}_{\text {cep }} \\
/ \mathrm{H} /\end{array}$ & $\begin{array}{c}\mathrm{B} 3, \mathrm{~m}_{\text {мax }} \\
/ \mathrm{H} /\end{array}$ & $\begin{array}{c}\mathrm{B} 1, \mathrm{~m}_{\min } \\
/ \mathrm{H} /\end{array}$ & $\begin{array}{c}\mathrm{B} 1, \mathrm{~m}_{\text {cep }} \\
/ \mathrm{H} /\end{array}$ & $\begin{array}{c}\mathrm{B} 1, \mathrm{~m}_{\text {мах }} \\
/ \mathrm{H} /\end{array}$ \\
\hline 8000 & 1,23 & 10,43 & 35,04 & 3,55 & 31,19 & 104,78 \\
\hline 12000 & 4,82 & 46,77 & 103,11 & 8,15 & 79,08 & 174,34 \\
\hline 15000 & 8,14 & 74,26 & 163,02 & 12,94 & 118,05 & 259,15 \\
\hline 18000 & 12,32 & 107,21 & 235,35 & 18,68 & 162,56 & 356,86 \\
\hline
\end{tabular}




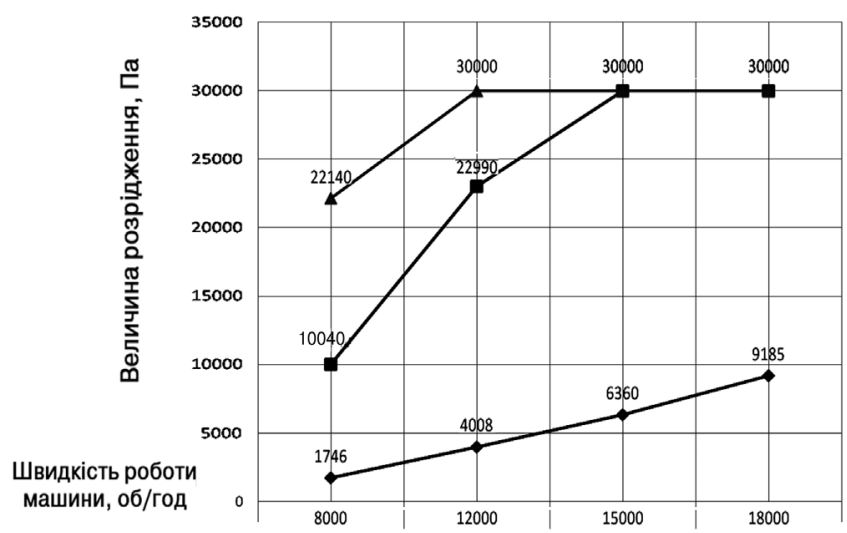

Рис. 4. Залежність величини розрідження від формату, маси та швидкості роботи машини

де $\mathrm{p}$ - величина розрідження, яка визначається з формули (6); $\mathrm{S}_{\mathrm{k}}$ - площа контакту сповільнюючого пристрою і листа.

Дослідження проводилось для листів формату В3 та В1 3 граматурою від 30 до 250 г/м² на швидкостях роботи машини $8000,12000,15000$ та 18000 від/год. Результати зусиль, що діють на відбиток в процесі виведення та укладання, наведені в табл. 2 та 3. Аналіз отриманих результатів показав (табл. 4), що існуючі варіанти зниження швидкості руху листів на попередніх стадіях для середніх (50×70) та великих форматів (від $70 \times 100$ і більше), а також для малих $(30 \times 50)$ з максимальним заповненням листа, не достатньо ефективні.

Третя стадія характеризується необхідністю забезпе-

Таблиця 3

Сила інерції листів в залежності від формату, маси матеріалів та швидкості машини

\begin{tabular}{|c|c|c|c|c|c|c|}
\hline $\begin{array}{c}\text { Швидкість } \\
\text { об/год }\end{array}$ & $\begin{array}{c}\mathrm{B} 3, \mathrm{~m}_{\min } \\
/ \mathrm{H} /\end{array}$ & $\begin{array}{c}\mathrm{B} 3, \mathrm{~m}_{\text {cep }} \\
/ \mathrm{H} /\end{array}$ & $\begin{array}{c}\mathrm{B} 3, \mathrm{~m}_{\text {мax }} \\
/ \mathrm{H} /\end{array}$ & $\begin{array}{c}\mathrm{B} 1, \mathrm{~m}_{\min } \\
/ \mathrm{H} /\end{array}$ & $\begin{array}{c}\mathrm{B} 1, \mathrm{~m}_{\text {cep }} \\
/ \mathrm{H} /\end{array}$ & $\begin{array}{c}\mathrm{B} 1, \mathrm{~m}_{\text {мax }} \\
/ \mathrm{H} /\end{array}$ \\
\hline 8000 & 0,0684 & 0,272 & 0,5667 & 0,1342 & 0,5338 & 1,1112 \\
\hline 12000 & 0,1662 & 0,6607 & 1,3763 & 0,3274 & 1,3024 & 2,7111 \\
\hline 15000 & 0,2668 & 1,0607 & 2,2096 & 0,5234 & 2,0819 & 4,3337 \\
\hline 18000 & 0,3865 & 1,5362 & 3,2001 & 0,7605 & 3,025 & 6,297 \\
\hline
\end{tabular}

Таблиця 4 Швидкість відбитка в момент його відпускання захоплювачами залежно від формату, маси та швидкості роботи машини

\begin{tabular}{|c|c|c|c|c|c|c|}
\hline $\begin{array}{c}\text { Швидкість } \\
\text { (об/год) }\end{array}$ & $\begin{array}{c}\mathrm{B} 3, \mathrm{~m}_{\min } \\
(\mathrm{M} / \mathrm{c})\end{array}$ & $\begin{array}{c}\mathrm{B} 3, \mathrm{~m}_{\text {сер }} \\
(\mathrm{M} / \mathrm{c})\end{array}$ & $\begin{array}{c}\mathrm{B} 3, \mathrm{~m}_{\text {мax }} \\
(\mathrm{M} / \mathrm{c})\end{array}$ & $\begin{array}{c}\mathrm{B} 1, \mathrm{~m}_{\min } \\
(\mathrm{M} / \mathrm{c})\end{array}$ & $\begin{array}{c}\mathrm{B} 1, \mathrm{~m}_{\text {cep }} \\
(\mathrm{M} / \mathrm{c})\end{array}$ & $\begin{array}{c}\mathrm{B} 1, \mathrm{~m}_{\text {мax }} \\
(\mathrm{M} / \mathrm{c})\end{array}$ \\
\hline 8000 & 0,585 & 0,845 & 1,17 & 0,922 & 1,103 & 1,222 \\
\hline 12000 & 0,875 & 1,267 & 2,15 & 1,383 & 1,772 & 2,706 \\
\hline 15000 & 1,097 & 1,856 & 3,287 & 1,729 & 2,948 & 3,647 \\
\hline 18000 & 1,316 & 3,263 & 4,272 & 2,075 & 3,923 & 4,528 \\
\hline
\end{tabular}


чення гарантованого підходу віддрукованих листів до передніх упорів з максимально допустимою швидкістю $\mathrm{V}_{\text {д }}=0,8 \mathrm{~m} / \mathrm{c}$ та укладання їх у стапель за рахунок аеродинамічного падіння внаслідок дії сил інерції, а також направлених потоків повітря, які створюються повітряною системою приймального пристрою.

На цій стадії необхідно забезпечити суттєве зниження швидкості виводу відбитків (див. табл. 4). Це досягається встановленням на приймальному модулі гальмівних та додаткових пристроїв, які спрацьовують в момент відпускання відбитка захоплювачами вивідного ланцюгового транспортера (рис. 5).

Слід враховувати, що величина сили гальмування обмежена і залежить від технічних параметрів вакуумної системи сповільнюючого пристрою. Для підвищення ефективності приймального пристрою і збереження максимально допустимої швидкості друкування рекомендується використовувати систе-

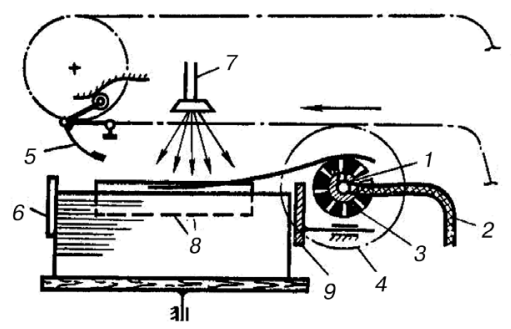

a му вентиляторів з направленою дією потоків повітря. Така система складається з рами, на якій закріплені вентилятори та повітроводи. В залежности від типу машини, формату продукції та конфігурації приймального пристрою, на рамі може бути встановлена різна кількість вентиляторів, так в офсетних друкарських машинах формату В3 встановлено 6 вентиляторів, а в машинах формату В1 - до 15.

Для ефективного використання системи вентиляторів та можливості управління ними необхідно визначити величину зусилля, яке може бути створено повітряним потоком. Для цього, використовуючи залежности (2) і (3), визначаємо швидкість відбитку і, підставляючи отримані дані у формулу (4), визначаємо величину зусилля, яке необхідно створити додатково направленими потоками повітряної системи для забезпечення руху листа та його укладання у стапель. При розрахунках враховуємо також, що величина аеродиначної сили $\mathrm{F}_{\mathrm{a}}{ }^{\prime}$

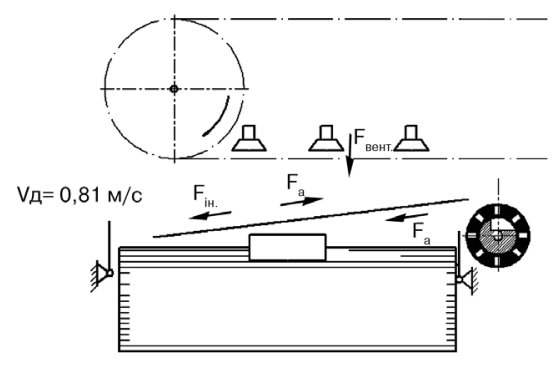

б

Рис. 5. Процес виведення та укладання віддрукованої продукції у стапель (а - загальний вид приймального пристрою: 1 - вакуумні елементи сповільнюючого пристрою; 2 - повітроводи; 3 - вакуумні камери; 4 - приводна зірочка; 5 - захоплювачі ланцюгового транспортера; 6 - передні упори; 7 - сопла системи подачі повітря; 8 - бокові зіштовхувачі; 9 - задні зіштовхувачі; б - розрахункова схема) 
змінюється при виведенні відбитків в залежності від швидкості їх руху $\mathrm{V}_{\mathrm{a}}^{\prime}$ (при розрахунках приймаємо, що густина повітря $\rho_{0}==1,205 \mathrm{\kappa г} / \mathrm{M}^{3}$ і коефіцієнт опору $\mathrm{K}_{0}=0,026 \in$ сталими величинами). Таким чином отримуємо для кожного випадку силу від направленої дії повітря $\mathrm{F}_{\text {вент. }}$ :

$$
F_{\text {вент. }}=\left(m\left(V_{\mathrm{g}}^{\prime}\right)^{2}-V_{\mathrm{g}}^{2}\right) / 2 L_{y}^{\prime}-F_{a} .
$$

Сила $\mathrm{F}_{\text {вент. }} \in$ величиною сумарною і приведеною до центру відбитка. При цьому повітряні потоки можуть бути розділеними і мати індивідуальне управління, що дозволяє змінювати від центру до кромок відбитка напрям та тиск потоку повітря. Зміна напрямку повітряного потоку відбувається за рахунок повороту вентиляторів на певний кут відносно вертикалі. При рівномірному розподілу потоку лист притискається до стапеля по всій площині, при цьому в стопі між відбитками залишається частина повітря, яке приводить до спотворення геометрії стопи і необхідності додаткових операцій на стадії її обробки. Використання повіт- ряних систем 3 направленими потоками гарантує формування «правильного» стапеля. Для цього кожне сопло на рамі повітродувної системи повинно мати можливість регулювання зміни кута дії повітряного потоку відповідно до вимог, ситуації та характеристик задруковуваних матеріалів, таких як граматура, формат, кількість нанесеної фарби, розміщення друкуючих елементів та швидкості роботи машини (рис. 6).

При цьому сили натиску від потоків повітря $\mathrm{F}_{\text {вент. } 1}-\mathrm{F}_{\text {вент.5 }}$ Можуть мати змінні значення. Можливість окремого регулювання кутів нахилу сопел $\alpha, \beta, \gamma$ та $\delta$ дозволить змінювати величину вертикальної складової від дії потоків повітря. Отже, наявність системного регулювання кожної складової може суттєво підвищити ефективність роботи системи.

Ще одним способом оптимізації роботи приймальновивідних пристроїв $є$ регульоване ввімкнення системи сповільнення. Наприклад, при роботі 3 тонкими матеріалами (граматурою до 30-60 г/м²) на

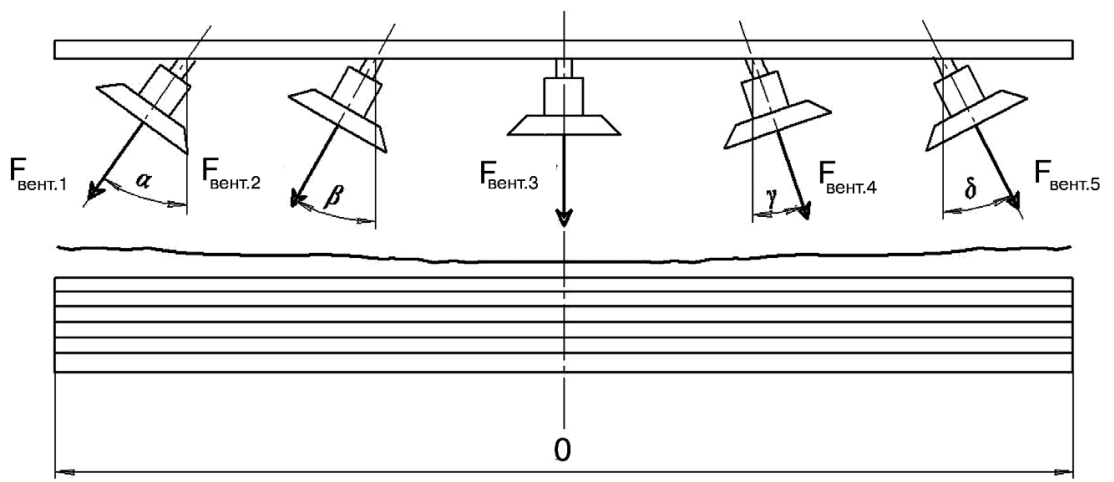

Рис. 6. Схема оптимізації повітродувної системи 
швидкостях друкування до 12000 від/год підключається лише частина сповільнювачів. Також можливо використання повітродувних пристроїв у вигляді регульованих повітряних трубок, розташованих над вакуумним модулем і сприяючих покращенню присмоктування задньої кромки листа до сповільнюючого пристрою.

Покращення якості формування стопи віддрукованої продукції може бути досягнуто за рахунок використання повітродувних пристроїв відведення надлишків повітря з під відбитку, що сприяє утворенню рівномірної повітряної подушки і робить поведінку відбитка більш прогнозованою.

Для виведення та укладання відбитків та формування якісного прийомного стапеля при роботі з великими форматами (від 70×100 і більше), можуть використовуватися додаткові модулі для перехоплення та укладання листів у стапель, де за рахунок зміни траєкторії руху та збільшення кількості захоплювачів в системі перехоплення досягається безударне доведення листів до передніх упорів і точне укладання відбитків у стапель.

\section{Висновки}

Умови роботи друкарських машин внаслідок зростання швидкості друкування, розширення спектру матеріалів, росту вимог до зовнішнього вигляду продукції та її різноманіття постійно змінюються. Це потребує конструкційних змін приймально-вивідних пристроїв, які суттєво впливають на якість кінцевої продукції, адже навіть при бездоганній роботі всіх попередніх секцій машини невідповідна робота механізмів приймальновивідних пристроїв може звести нанівець всю попередню роботу.

В результаті проведеного дослідження були запропоновані певні напрямки оптимізації існуючих конструкцій приймальновивідних пристроїв шляхом зміни налаштувань існуючих пристроїв та розширення сфери застосування вже встановлених пристроїв, а також введенням допоміжних конструктивних елементів. Вище зазначені способи допоможуть забезпечити ефективність роботи із розширеним спектром матеріалів та зростаючими швидкостями роботи машини.

1. Чехман Я. І. Друкарське устаткування : Підручник / Я. І. Чехман, В. Т. Сенкусь, В. П. Дідич, В. О. Босак. - Львів : УАД, 2005. - С. 357-367. 2. Тюрин А. А. Печатные машины : Уч. пособ. / А. А. Тюрин. - М. : Книга, 1980. - С. 350-361. 3. Митрофанов В. П. Печатное оборудование : Уч. пособ. / В. П. Митрофанов. - М. : Изд-во МГУП. - 1999. - 442 с. 4. Конструкція аркушевих ротаційних друкарських машин. - Львів : УАД, 2005. - 60 с. 5. Козаровицкий Л. А. Бумага и краска в процессе печатания / Л. А. Козаровицкий. - М. : Книга. - 1965. - 366 с. 6. Примаков С. П. Технологія паперу і картону / С. П. Примаков, В. А. Барабаш. - К. : ЕКМО. - 2002. - 396 с. 7. Кухлинг Х. Справочник по физике : Пер. с нем. / Х. Кухлинг. - М. : Мир, 1982. - С. 42-50, С. $72-83$, C. $117-119$, C. $195-196$. 
1. Chekhman la. I. Drukarske ustatkuvannia : Pidruchnyk / la. I. Chekhman, V. T. Senkus, V. P. Didych, V. O. Bosak. - Lviv : UAD, 2005. - S. 357-367. 2. Tjurin A. A. Pechatnye mashiny : Uch. posob. / A. A. Tjurin. - M. : Kniga, 1980. - S. 350-361. 3. Mitrofanov V. P. Pechatnoe oborudovanie : Uch. posob. / V. P. Mitrofanov. - M. : Izd-vo MGUP. - 1999. - 442 s. 4. Konstruktsiia arkushevykh rotatsiinykh drukarskykh mashyn. - Lviv : UAD, 2005. -60 s. 5. Kozarovickij L. A. Bumaga i kraska v processe pechatanija / L. A. Kozarovickij. - M. : Kniga. - 1965. - 366 s. 6. Prymakov S. P. Tekhnolohiia paperu i kartonu / S. P. Prymakov, V. A. Barabash. - Kyiv : EKMO. - 2002. - 396 s. 7. Kuhling H. Spravochnik po fizike : Per. s nem. / H. Kuhling. - M. : Mir, 1982. - S. 42-50, S. 72-83, S. 117-119, S. 195-196. 